\title{
Effects of metformin on insulin receptor tyrosine kinase activity in rat adipocytes
}

\author{
D. B. Jacobs, G. R. Hayes, J. A. Truglia and D. H. Lockwood
}

Endocrine-Metabolism Unit of the Department of Medicine, University of Rochester School of Medicine and Dentistry, Rochester, New York, USA

\begin{abstract}
Summary. The cellular mechanism(s) by which the biguanide, metformin, exerts its antihyperglycaemic effect was investigated. Rat adipocytes were either treated acutely $(2 \mathrm{~h})$ or maintained in a biochemically defined medium $(20 \mathrm{~h})$ in the presence or absence of metformin $\left(1 \times 10^{-4} \mathrm{~mol} / \mathrm{l}\right)$. Exposure to the drug resulted in a significant enhancement $(p<0.01)$ of hexose transport in both the absence (basal) and presence of insulin. Stimulation of transport was not explained by the increase in the basal state alone, since the incremental response to maximally effective concentrations of insulin was significantly enhanced $p<0.025$. Insulin-receptor tyrosine kinase activity was examined under the same experimental conditions.
\end{abstract}

Activity of the kinase was unaltered as evaluated by phosphorylation of an artificial substrate and by phosphorylation of the receptor in situ. Furthermore, in this investigation neither insulin receptor number nor affinity was changed in adipose tissue treated with metformin. These studies indicate that metformin potentiates the effect of insulin on glucose transport at a site(s) beyond insulin receptor binding and phosphorylation.

Key words: Insulin receptor - Tyrosine kinase activity - Intact cell phosphorylation - Metformin
Metformin ( $\mathrm{N}^{1} \mathrm{~N}^{1}$-dimethyl biguanide) is an oral antihyperglycaemic agent used in the management of Type 2 (non-insulin-dependent) diabetes mellitus [1]. Although the mechanism of action is not clearly understood, it has been shown that metformin can increase insulin binding in several mammalian cell types [2]. However, Cigolini et al. [3] found that metformin potentiates glucose metabolism in human adipose tissue without altering insulin binding. Metformin also potentiates insulin action in soleus muscle isolated from streptozotocin-treated, insulinopenic mice without influencing insulin binding [4]. These latter studies suggest that metformin can act at a post-binding site(s).

In the present study, we have utilized a rat adipose tissue maintenance system to further explore the mechanism(s) of action of metformin. The effects of metformin on glucose transport and phosphorylation of the insulin receptor were investigated. Phosphorylation of tyrosine residues by the insulin-receptor kinase was studied because of the suggestion that this kinase may be involved in linking insulin binding to the insulin effector system (for a review see reference 5).

\section{Materials and methods}

\section{Adipose tissue culture and cell isolation}

Epididymal fat pads were removed from male Sprague-Dawley rats (150-225 g, Charles Rivers Laboratories, Wilmington, Mass, USA) under sterile conditions and minced. The pieces were incubated with or without metformin $\left(1 \times 10^{-4} \mathrm{~mol} / \mathrm{l}\right.$; metformin was a generous gift of R. Vigneri, Catania, Italy) in Parker's medium 199 containing 3\% (wt/vol) bovine serum albumin (BSA), $1 \mathrm{~g} / 1$ bacitracin and $0.3 \mathrm{~g} / 1$ $\mathrm{N}$-2-hydroxy-ethylpiperazine- $\mathrm{N}^{\prime}$-2-ethanesulfonic acid (HEPES), $\mathrm{pH} 7.4$, at $37^{\circ} \mathrm{C}$ for $20 \mathrm{~h}$ under an atmosphere of $95 \% \mathrm{O}_{2}$ and $5 \% \mathrm{CO}_{2}$ [6]. When appropriate, metformin was present throughout the incuba* tion period and during subsequent cell isolation and assessment of insulin action and kinase activity. After $20 \mathrm{~h}$, the $\mathrm{pH}$ of the incubation medium in both control and metformin-treated groups decreased slightly to pH 7.2. Following the incubation, the minced tissue was washed with Krebs-Ringers phosphate buffer, $\mathrm{pH} 7.4$, which contained 3\%(wt $/ \mathrm{vol}) \mathrm{BSA}(\mathrm{KRP}-3 \% \mathrm{BSA})$; and isolated adipocytes prepared by collagenase $(1 \mathrm{~g} / 1$, Cooper Biomedical, Malvern, $\mathrm{Pa}, \mathrm{USA})$ digestion for $15 \mathrm{~min}$ at $37^{\circ} \mathrm{C}[6]$. When compared to control cells, metformin treatment did not alter cell size.

\section{Insulin binding}

Adipocytes were incubated with $1 \times 10^{-10} \mathrm{~mol} / 1^{125} \mathrm{I}$-iodoinsulin and $0-833 \mathrm{nmol} / 1$ native porcine insulin for $1 \mathrm{~h}$ at $21^{\circ} \mathrm{C}$ in KRP-3\% BSA. The assay was terminated by centrifuging the adipocytes through silicone oil [6]. Radioactivity bound at $833 \mathrm{nmol} / 1$ native hormone was used as a correction for nonspecific binding $(0.55 \%$ of total ${ }^{125}$ I-iodoinsulin added).

\section{Hexose uptake}

Aliquots of adipocytes in KRP-3\% BSA were incubated with varying concentrations of insulin $(0-7 \mathrm{nmol} / 1)$ at $37^{\circ} \mathrm{C}$ for $30 \mathrm{~min}$. 2-Deoxy$\mathrm{D}-\left[1{ }^{3} \mathrm{H}\right]$ - glucose $(0.1 \mathrm{mmol} / \mathrm{l})$ was then added, incubated for $90 \mathrm{~s}$, and the assay terminated by centrifugation through silicone oil [6]. Extracellular trapping of 2-deoxyglucose by the fat cell pellet (approxi- 


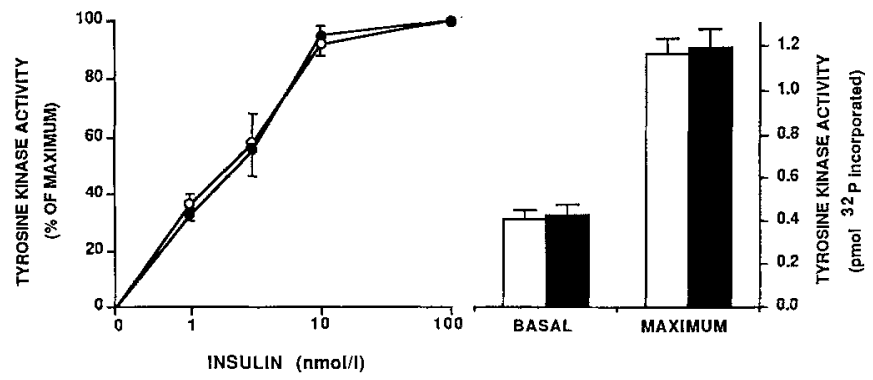

Fig. 1. Left Panel. Tyrosine kinase activity of the insulin receptor isolated from untreated $(O)$ and metformin $\left(1 \times 10^{-4} \mathrm{~mol} / 1\right)$-treated $(0)$ cells as measured by phosphorylation of $\mathrm{Glu}_{80} \mathrm{Ty}_{20}$. The results are expressed as mean percent \pm SEM of the maximal incremental response (insulin-basal) to insulin $(100 \mathrm{nmol} / 1)$ from four experiments performed in triplicate. Right Panel. Basal and maximal phosphorylation (pmol ${ }^{32} \mathrm{P} / \mathrm{fmol}$ insulin binding) for untreated (open bars) and metformin-treated (solid bars) cells from five separate experiments performed in triplicate

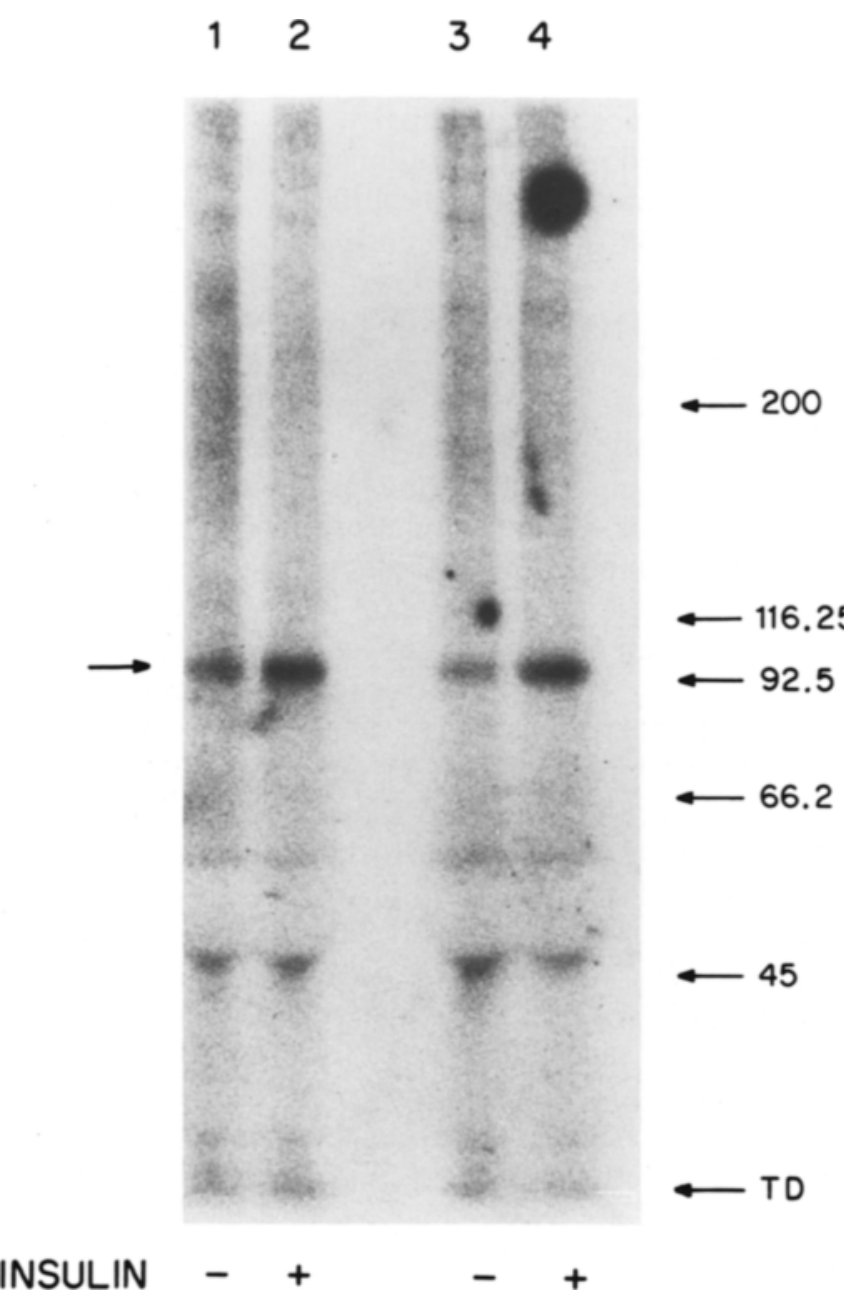

Fig. 2. Adipocytes from untreated (Lanes 1 and 2) and metformintreated (Lanes 3 and 4) tissue were equilibrated with ${ }^{32} \mathrm{PO}_{4}$ for $90 \mathrm{~min}$ at $37^{\circ} \mathrm{C}$. Cells were then incubated in the absence (Lanes 1 and 3 ) or presence (Lanes 2 and 4 ) of insulin $(100 \mathrm{nmol} / \mathrm{l})$ for $5 \mathrm{~min}$ at $37^{\circ} \mathrm{C}$. Insulin receptors were partially purified, immunoprecipitated, and subjected to SDS polyacrylamide gel electrophoresis as described in $\mathrm{Ma}$ terials and Methods. Arrows to the right indicate the migration of the molecular weight standards. Arrow to the left indicates the $\beta$-subunit of the insulin receptor. TD indicates migration of bromphenol blue tracking dye mately $12 \mathrm{pmol} / 10^{5}$ cells) was corrected for by parallel incubations in the presence of $50 \mathrm{umol} / 1$ cytochalasin $B$.

\section{Tyrosine kinase activity of the insulin receptor}

The ability of adipocyte insulin receptors, partially purified by wheat germ agglutinin-Sepharose chromatography, to phosphorylate Glu $_{80} \mathrm{Tyr}_{20}$ was measured as described by Hayes and Lockwood [7]. Insulin receptors were incubated with the indicated concentrations of insulin for $20 \mathrm{~min}$ at $24^{\circ} \mathrm{C}$ in a total volume of $50 \mathrm{ul}$. The substrate, ions, and $\left[\gamma^{32} \mathrm{P}\right]$ - ATP were added to the incubation in the concentrations previously described [7] and incubations continued for $20 \mathrm{~min}$ at $24^{\circ} \mathrm{C}$.

Phosphorylation of insulin receptors in intact cells was performed as described previously [7]. Isolated adipocytes $\left(1-3 \times 10^{6} \mathrm{cells} / \mathrm{ml}\right)$, pre-equilabrated with $\left[{ }^{32} \mathrm{P}\right]$-ortho-phosphate in phosphate-free KrebsRingers bicarbonate buffer supplemented with $25 \mathrm{mmol} / 1$ HEPES, $\mathrm{pH} 7.4$, containing $0.5 \% \mathrm{BSA}$ (wt/vol), were incubated for $5 \mathrm{~min}$ at $37^{\circ} \mathrm{C}$ in the absence or presence of insulin $\left(10^{-7} \mathrm{~mol} / \mathrm{l}\right)$. At the end of the incubation, the buffer was removed and the cells solubilized in the presence of phosphatase and protease inhibitors. Insulin receptors were partially purified on wheat germ agglutin-Sepharose also in the presence of phosphatase inhibitors. Insulin receptors were then immunoprecipitated by incubation $\left(16 \mathrm{~h}\right.$ at $\left.4^{\circ} \mathrm{C}\right)$ with a $1: 25$ dilution of antiserum to rat liver insulin receptor. Pansorbin ${ }^{\circledR}$ (Calbiochem, La Jolla, Calif, USA) was then added and the incubation continued at $4^{\circ} \mathrm{C}$ for an additional hour. Immunoprecipitates were collected by centrifugation and analyzed by sodium dodecyl sulfate polyacrylamide gel electrophoresis. Radioactive bands were detected by autoradiography using intensifying screens and results quantitated by densitometric scanning.

\section{Stastistical analysis}

Results are expressed as mean \pm SEM (with number of observations in parentheses). The significance of differences was assessed using Student's $t$-test. Values with $p<0.05$ were regarded as significant.

\section{Results}

The effect of metformin on glucose transport was investigated in rat adipocytes. These determinations were made to demonstrate that the drug potentiates insulin action in this system by post-binding mechanisms [3, 4]. Insulin-stimulated transport of the D-glucose analog, 2-deoxyglucose, was enhanced by metformin treatment for $20 \mathrm{~h}$. The incremental response to insulin $(7 \mathrm{nmol} / \mathrm{l})$ was increased 19\% (untreated: $89.2 \pm 15.0 \mathrm{pmol} / 10^{5}$ cells $/ 90 \mathrm{~s}$; metformin: $106.2 \pm 16.5 \mathrm{pmol} / 10^{5} \mathrm{cells} / 90 \mathrm{~s}$; $n=5, p<0.025$ ). In data not shown, metformin treatment had no effect on the insulin sensitivity of the adipocytes (1/2 maximal effective concentration $=0.18 \mathrm{nmol} / \mathrm{l})$. Furthermore, $20 \mathrm{~h}$ metformin treatment caused a small but significant increase $(p<0.01)$ in basal transport. However, under these conditions metformin had no effect on the binding of ${ }^{125}$ I-iodoinsulin to adipocytes (data not shown). Thus, metformin potentiated glucose transport in these cells via a postbinding mechanism(s). This conclusion is similar to the findings of others $[3,4]$ assessing different parameters of insulin action.

The influence of metformin on tyrosine kinase activity of the insulin receptor was next examined. As shown 
in Figure 1 (right panel), $20 \mathrm{~h}$ metformin treatment alone had no effect on phosphorylation of the synthetic peptide $\mathrm{Glu}_{80} \mathrm{Tyr}_{20}$. In five experiments, phosphorylation of the substrate by purified receptors from untreated cells was stimulated approximately 3 -fold by $100 \mathrm{nmol} / 1$ insulin. Metformin treatment in combination with any of the insulin concentrations tested did not alter kinase activity (Fig. 1, left panel). The insulin sensitivity of kinase activity was also unaltered by metformin treatment; the concentration required for halfmaximal substrate phosphorylation was approximately $3 \mathrm{nmol} / 1$ with receptors from both treated and untreated tissue.

The effect of metformin treatment on phosphorylation of the insulin receptor was evaluated following incubation of intact cells with [ $\left.{ }^{32} \mathrm{P}\right]$-ortho-phosphate. An autoradiogram from a typical experiment is shown in Fig. 2. Phosphorylation of a single protein $\mathrm{Mr}=94,000$, previously shown to be the $\beta$-subunit of the insulin receptor [5, 7], was stimulated by insulin $(100 \mathrm{nmol} / 1)$. Metformin alone did not alter phosphorylation of this band. Phosphorylation of this protein was increased $2.88 \pm 0.46$-fold by insulin in untreated cells and $2.87 \pm$ 0.50 -fold in metformin-treated adipocytes $(n=4$, $\mathrm{p}=\mathrm{N}$.S.). These data, in agreement with the results using partially purified receptors, indicate that metformin had no discernable effect on insulin receptor phosphorylation.

Additional experiments indicated that $2 \mathrm{~h}$ metformin treatment potentiated 2-deoxyglucose transport without an effect on insulin binding. We also found in these experiments that tyrosine kinase activity of the insulin receptor was unaffected by $2 \mathrm{~h}$ metformin-treatment (data not shown).

\section{Discussion}

Biguanides are oral antidiabetic agents used in the treatment of Type 2 diabetes. Since biguanides are not pancreatic secretogogues, several investigators have focused on the effects of these drugs on target tissues for insulin. In vitro studies have indicated that metformin can increase insulin binding in several cell types including MCF-7 human breast cancer cells, IM-9 human lymphocytes, human fibroblasts and $\mathrm{H}-35$ rat haepatoma cells [2]. Other studies have demonstrated increased glucose oxidation and lipogenesis in human fat cells [3] and increased glycogen synthesis in mouse soleus muscle, without an alteration in insulin binding [4]. These latter findings suggest that post-binding actions of metformin play a major role in the increase in glucose uptake in these tissues.

Previously we have shown the value of adipose tissue maintained in a chemically defined environment in the evaluation of the hypoglycaemic effects of sulfonylureas [6]. In the present study metformin, acutely and chronically, potentiates insulin-stimulated glucose transport without an alteration of insulin binding to its receptor. These data confirm and extend the work by Cigolini et al [3], demonstrating the post-binding action of metformin in fat cells. It is interesting to note that, unlike our previous findings with sulfonylureas, metformin treatment also stimulates glucose uptake and metabolism (unpublished observation) in the absence of insulin.

Since metformin enhanced insulin action by a postbinding mechanism(s), it was of interest to determine if metformin altered the phosphorylation state of the insulin receptor. This was important for at least two reasons: 1) it has been suggested that increased tyrosine kinase activity of the insulin receptor is the initial step in the transmission of a signal coupling insulin binding to insulin action [5]; 2) it is well known that the site of insulin resistance associated with Type 2 diabetes mellitus resides largely beyond the binding portion of the insulin receptor. Thus, it is possible that antihyperglycaemic agents used in the treatment of this disease may act by causing enhanced kinase activity.

We studied phosphorylation of rat adiopcyte insulin receptors in both intact and cell-free systems for several reasons: (1) phosphorylation using partially purified receptors can be easily quantitated; (2) in situ phosphorylation more closely reflects the physiologic state; (3) we have recently noted the discrepancy that the oxidant $\mathrm{H}_{2} \mathrm{O}_{2}$ enhances phosphorylation in situ but not with partially purified receptors [8]. In both systems, the phosphorylating activity of the insulin-receptor tyrosine kinase was unaffected by metformin while insulin action was enhanced. Since receptor purifications were carried out at $4{ }^{\circ} \mathrm{C}$ and protease inhibitors and metformin were present throughout, we feel it is unlikely that kinase activity was lost during preparation of insulin receptors. Furthermore, we saw no effect of metformin on the tyrosine kinase activity in intact cells where phosphatase inhibitors were also present. A lack of a shift in the dose-response curve for insulin-stimulated glucose transport following metformin treatment provides further evidence that this drug has no effect on kinase activity. As discussed by Arsenis and Livington [9], the presence of "spare" insulin binding sites in fat cells implies that the kinase activity is also "spare". Thus, any alteration in this activity should produce a change in the dose-response curve for insulin action in the same manner as that produced by an alteration in insulin binding.

We found an average increase of $22 \%$ in insulin action following metformin treatment. Although these changes are small, it is probable that equivalent changes in kinase activity could have been detected. In this regard Lemarchand-Brustel et al. [10] reported a 20\% reduction in insulin-stimulated receptor kinase activity in skeletal muscle from 10-week old obese mice. This was in direct proportion to the decrease in insulin binding.

Based on these considerations, which include the examination of two different measures of kinase activity, we believe that metformin potentiates insulin-stimu- 
lated glucose transport without altering the enzyme activity. Further investigation of the pharmacologic action of biguanides requires examination of steps distal to the insulin receptor such as "second messengers" and translocation of glucose transporters.

Acknowledgements. The investigators are appreciative for the excellent technical assistance of G. LaCourse and S. Wall, and for the superb secretarial skills of E.Skelton. This study was supported by grants from the National Institutes of Health, Training Grant NIH T32 AM-07092 (DBJ), NIH RO1 AM-20129 (DHL), NIH INRSA F32 AM-07735 (JAT), a grant from the New York State Health Research Council, NYS HRCF D 2-039 (GRH) and a grant from Lipha Chemical Inc.

\section{References}

1. Hermann, LS (1979) Metformin: a review of its pharmacological properties and therapeutic use. Diabetes Metab 5:233-245

2. Vigneri R, Pezzino V, Wong KY, Goldfine ID (1982) Comparison of the in vitro effects of biguanides and sulfonylureas on insulin binding to its receptor in target cells. J Clin Endocrinol Metab 54: $95-100$

3. Cigolini M, Bosello O, Zancanaro C, Orlandi PG, Fezzi O, Smith $U$ (1984) Influence of metformin on metabolic effect of insulin in human adipose tissue in vitro. Diabete Metabolisme 10:311-315
4. Lord JM, Puah JA, Atkins TW, Bailey CJ (1985) Postreceptor effect of metformin on insulin action in mice. J Pharm Pharmacol 37: 821-823

5. Cobb MH, Rosen OM (1984) The insulin receptor and tyrosine protein kinase activity. Biochim Biophys Acta 738:1-8

6. Maloff BL, Lockwood DH (1981) In vitro effects of a sulfonylurea on insulin action in adipocytes. J Clin Invest 68: 85-90

7. Hayes GR, Lockwood DH (1986) The role of cell surface sialic acid in insulin receptor function and insulin action. $\mathrm{J}$ Biol Chem 261: $2791-2798$

8. Hayes GR, Lockwood DH (1986) Stimulation of insulin receptor (IR) phosporylation by $\mathrm{H}_{2} \mathrm{O}_{2}$ in intact adipocytes. Diabetes 35 [Suppl 1]: $2 \mathrm{~A}$

9. Arsenis G, Livingston JN (1986) Alterations in the tyrosine kinase activity of the insulin receptor produced by in vitro hyperinsulinemia. J Biol Chem 261: 147-153

10. LeMarchand-Brustel $Y$, Gremeaux T, Ballotti R, Van Obberghen $E$ (1985) Insulin receptor tyrosine kinase is defective in skeletal muscle of insulin-resistant obese mice. Nature 315: 676-679

Received: 3 March 1986

and in revised form: 23 September 1986

Dr. Dean H.Lockwood

Box 693

University of Rochester Medical Center

Rochester, NY 14642, USA 